\title{
Effect of Training on the Application of ANC 10 T on Midwife Knowledge to Prevent Maternal Death in Dairi Regency of North Sumatra Indonesia
}

\author{
Samsider Sitorus ${ }^{1}$, Emy Rianti $^{2} \&$ Juliani Purba $^{3}$ \\ ${ }^{1}$ Midwifery Department of Ministry Health of Polytechnic Medan, Indonesia \\ ${ }^{2}$ Midwifery Department of Ministry Health of Polytechnic Jakarta 1, Indonesia \\ ${ }^{3}$ Midwifery Department P. Siantar of Ministry Health Polytechnic Medan, Indonesia \\ Correspondence: Samsider Sitorus, Midwifery Department of Ministry Health of Polytechnic Medan, Indonesia. \\ Tel: 62-812-659-2472.
}

Received: November 30, 2020 Accepted: January 19, 2021 Online Published: February 5, 2021

doi:10.5539/gjhs.v13n3p70 URL: https://doi.org/10.5539/gjhs.v13n3p70

\begin{abstract}
Introduction: Antenatal Care (ANC) data collected at Matlab Thana and shows that the maternal mortality rate for mothers aged $15-19$ years is 7.4 per 1000 live births while for mothers aged $20-24$ it is 3.8 to 1000 live births. For mothers under the age of $15,17,7$. This ratio was then cited in the 1989 WHO volume compilation of age-specific maternal mortality data from 40 countries over approximately the same period as the Bangladesh study suggesting a much more moderate risk of excess for young mothers, but most of them were ignored in the scientific literature. Rizki Dewi et al's 2017 research-led most midwives (69.7\%) 10T standard in good integrated antenatal service. The purpose of the research to know the knowledge of midwives in the application of antenatal care to prevent maternal death in Dairi Regency of North Sumatra.
\end{abstract}

Methods: Design research was quantitative research with a quantitative design experiment. Models used, observed/measured changes. Bivariate Analysis, to analyze the influence between independent variables (each dimension) and dependent variables with different tests (t-tests).

Research Results: Midwife knowledge increased after ANC implementation training. Knowledge Before an ANC $10 \mathrm{~T}$ application training, value $\mathrm{p}=0.731$ This means that there was no difference in knowledge, control before (pre-test) training implementation of ANC $10 \mathrm{~T}$. The average knowledge difference between the pre-test and post-test is 0.067 with a value of $\mathrm{p}=0.058$ The difference between the case group and the control group before and after the training of an ANC $10 \mathrm{~T}$ implementation with a value of $\mathrm{p}=0.000$, $\mathrm{p}$-value $(0.000)<0.05$ then it can be concluded that the training of the implementation of ANC 10 T effectively improves midwife knowledge in Dairi Regency of Sumatra Province.

Conclusion: Midwife knowledge increased after an ANC implementation training in the Dairi regency of North Sumatra. Advice that training was very effective to improve the knowledge of midwives in the application of ANC in Dairi district of North Sumatra.

Keywords: midwife knowledge, training on the application of ANC $10 \mathrm{~T}$

\section{Introduction}

Antenatal Care (ANC) data collected at Matlab Thana shows that the maternal mortality rate for mothers aged 1519 years was 7.4 per 1000 live births while for mothers aged 20-24 it was 3.8 to 1000 live births. For mothers under the age of 15 , was 17,7 . This ratio was then cited in the 1989 WHO volume compilation of age-specific maternal mortality data from 40 countries over approximately the same period as the Bangladesh study suggesting a much more moderate risk of excess for young mothers, but most of them were ignored in the scientific literature. (Nove et al., 2014; Nortman, 1974). Rizki Dewi et al.'s 2017 research-led most midwives (69.7\%) to perform 10T standards in a well-integrated antenatal service (Risqi et al., 2017).

Antenatal visits for monitoring and monitoring of maternal and child well-being at least four times during pregnancy in time, i.e. up to trimester I pregnancy ( $<14$ weeks) one visit, and pregnancy trimester II (14-28 weeks) one visit, and pregnancy trimester III (28-36 weeks and after the 36th week) two visits. Nationally the target for 
antenatal care visits is $90 \%$. Assessment of the implementation of maternity health services can be done by looking at the coverage of K1 and K4 (Ministry of Health, 2017).

Coverage of maternal pregnancy screening in Indonesia based on data from Basic Health Reset (Riskesdas) in 2018 overall there are $96.1 \%$ of mothers who check their pregnancy in health workers. Meanwhile, the coverage of the proportion of pregnancy screening in Indonesia $\mathrm{K} 1$ is $86.0 \%$ and $\mathrm{K} 4$ was $74.1 \%$ (Health, 2018).

Intensive field observations in recent years have shown that antenatal services are still focused on the $7 \mathrm{~T}$ service. Integrated antenatal service for examination using $10 \mathrm{~T}$ (Weigh weight and measure height, measure blood pressure, nutritional status value, measure high abdominal, determine the fetal presentation and fetal heart rate, screening of immunization status TT, blood added tablets, laboratory check, procedure/case management, interview). This standard of examination is expected to provide quality antenatal services to improve maternal health status which will ultimately contribute to the decrease in maternal mortality rate (Ministry of Health, 2015). The referral system in obstetric service mechanisms was an abundance of reciprocal responsibility for cases or obstetric problems arising both vertically and horizontally.

2. Methods and Materials

Design research is quantitative research with quasi-experiments. Models used, changes observed/ measured

ANC $10 \mathrm{~T}: \mathrm{O} 1 \square \mathrm{X} 1 \square \mathrm{O} 2$ Implementation

ANC NON 10 T: O3 $\square \mathrm{X} 2 \square \mathrm{O} 4$

Description:

O1: Midwives before ANC $10 \mathrm{~T}$ Implementation Training

O2: Midwives after ANC $10 \mathrm{~T}$ Implementation Training

$\mathrm{X} 1$ : ANC $10 \mathrm{~T}$ Training

03: Midwife before ANC $10 \mathrm{~T}$ pre-test

04: Midwife After Implementation training of ANC $10 \mathrm{~T}$

$\mathrm{X}$ : No ANC $10 \mathrm{~T}$ Implementation Training

The population of this study is all midwives in Dairi Regency. The sample was a midwife who conducted the antenatal examination in Dairi Regency with purposive sampling technique. Inclusion criteria include 1. Midwives who have worked for more than 5 years; 2 . Midwives domiciled in the village; 3 . Midwives who are physically and spiritually healthy; 4 . Willing to be a respondent. Bivariate analysis, to analyze the influence between independent variables (each dimension) and dependent variables with different tests (t-tests).

\section{Research Results}

The research was conducted in Dairi Regency with a sample of 150 midwives divided into 2 groups, namely 75 people who were given training interventions in the application of ANC $10 \mathrm{~T}$ and 75 people without training. This study obtained the characteristics of respondents (age, education, and length of work), knowledge, midwives about the application of ANC $10 \mathrm{~T}$.

Table 1. Frequency distribution of respondents' characteristics by age, education, and length of work at intervention and control group

\begin{tabular}{llllll}
\hline \multirow{2}{*}{ No } & Variable & \multicolumn{2}{c}{ Intervention } & \multicolumn{2}{c}{ Control } \\
\cline { 3 - 6 } & & $\mathbf{f}$ & $\mathbf{\%}$ & $\mathbf{f}$ & $\mathbf{\%}$ \\
\hline I & Age & & & & 45,3 \\
\hline 1 & $30-39$ year & 32 & 42,7 & 34 & 46,7 \\
2 & $40-49$ year & 37 & 49,3 & 6,0 & $\mathbf{1 0 0 , 0}$ \\
3 & $\geq 50$ year & 6 & 8,0 & $\mathbf{7 5}$ & 84,0 \\
\hline II & Education & $\mathbf{7 5}$ & $\mathbf{1 0 0 , 0}$ & & 63 \\
\hline 1 & Diploma III & & & & \\
\hline
\end{tabular}




\begin{tabular}{llllll}
\hline 2 & Diploma IV / Bachelor's Degree & 15 & 20,0 & 12 & 16,0 \\
\hline & Total & $\mathbf{7 5}$ & $\mathbf{1 0 0 , 0}$ & $\mathbf{7 5}$ & $\mathbf{1 0 0 , 0}$ \\
\hline III & Long Working Time & & & 28 & 37,3 \\
\hline 1 & $<10$ year & 26 & 34,7 & 47 & 62,7 \\
\hline 2 & $\geq 10$ year & 49 & 65,3 & $\mathbf{1 5}$ & $\mathbf{1 0 0 , 0}$ \\
\hline
\end{tabular}

Based on Table 1 above it was known that the age of respondents in the intervention group and the control group was 30 years old to 50 years. The majority of respondents were aged $40-49$ years with a total of 37 people (49.3\%) intervention group and 35 people $(46.7 \%)$ control group, followed by $30-39$ years old as many as 32 people (42.7\%) intervention group and 34 people (45.3\%) control group. Based on education it is known that the majority of respondents educated diploma III with the number of 60 people $(80.0 \%)$ intervention group and 63 people $(84.0 \%)$ control group. Based on the length of employment it is known that the majority of respondents have worked more than 10 years with a total of 49 people (65.3\%) intervention group and 47 people $(62.7 \%)$ control group.

\subsection{Respondents' Knowledge about the Application of ANC $10 \mathrm{~T}$}

Knowledge was obtained based on respondents' answers to 10 knowledge questions about the Application of ANC $10 \mathrm{~T}$. To see the effectiveness of training in the application of ANC $10 \mathrm{~T}$ was carried out 2 times, namely before conducting training on the application of ANC $10 \mathrm{~T}$ (pretest) and after conducting training on the application of ANC (post-test). The 10 questions asked are worth 1 if true and 0 if incorrect with a value each between $0-10$.

Table 2. Distribution of Respondents' Knowledge Before and After training on the implementation of ANC $10 \mathrm{~T}$ in Dairi Regency

\begin{tabular}{|c|c|c|c|c|c|c|c|c|c|}
\hline \multirow{3}{*}{ No } & \multirow{3}{*}{ Knowledge } & \multicolumn{4}{|c|}{ Intervention } & \multicolumn{4}{|c|}{ Control } \\
\hline & & \multicolumn{2}{|c|}{ Pre-test } & \multicolumn{2}{|c|}{ Pos-test } & \multicolumn{2}{|c|}{ Pre-test } & \multicolumn{2}{|c|}{ Pos-test } \\
\hline & & f & $\%$ & f & $\%$ & f & $\%$ & f & $\%$ \\
\hline 1 & 5 & 2 & 2,7 & 0 & 0,0 & 2 & 2,7 & 1 & 1,3 \\
\hline 2 & 6 & 4 & 5,3 & 0 & 0,0 & 4 & 5,3 & 3 & 4,0 \\
\hline 3 & 7 & 13 & 17,3 & 1 & 1,3 & 10 & 13,3 & 12 & 16,0 \\
\hline 4 & 8 & 25 & 33,3 & 7 & 9,3 & 26 & 34,7 & 24 & 32,0 \\
\hline 5 & 9 & 21 & 28,0 & 27 & 36,0 & 23 & 30,7 & 25 & 33,3 \\
\hline \multirow[t]{2}{*}{6} & 10 & 10 & 13,3 & 40 & 53,3 & 10 & 13,3 & 10 & 13,3 \\
\hline & Total & 75 & 100,0 & 75 & 100,0 & 75 & 100,0 & 75 & 100,0 \\
\hline \multicolumn{2}{|c|}{ Average value } & \multicolumn{2}{|c|}{8,19} & \multicolumn{2}{|l|}{9,41} & \multicolumn{2}{|l|}{8,25} & \multicolumn{2}{|c|}{8,32} \\
\hline
\end{tabular}

Based on Table 2, it was known that in the prior knowledge (pretes) the intervention group had an average value of 8.19 and almost the same as the control group i.e. an average score of 8.25. After training in the application of ANC $10 \mathrm{~T}$, there was an increase in the average knowledge value in the intervention group to 9.41. Knowledge in the control group at the time post-test had an average score of 8.32. Most of the respondents' knowledge on pre-test with a score of 8 was 25 people (33.3\%) intervention group and 26 people (34.7\%) control group. After training on the application of ANC $10 \mathrm{~T}$, knowledge in the intervention group, most have a score of 10 , namely 40 people $(53.3 \%)$ while in the control group had a score of 9 (nine), namely 25 people (33.3\%) post-test.

\subsection{Bivariate Analysis}

\subsubsection{Differences in Knowledge, before and after an ANC $10 \mathrm{~T}$ Implementation Training}

Differences in knowledge before and after the ANC $10 \mathrm{~T}$ implementation training compared to respondents' knowledge before and after being given $10 \mathrm{~T}$ implementation training. The difference in knowledge was measured by pre-test and post paired tests. The results are as shown in the table below. 
Table 3. Distribution of differences in knowledge values, before and after $10 \mathrm{t}$ implementation training in Dairi regency

\begin{tabular}{|c|c|c|c|c|c|}
\hline Variable & & Mean & SD & Mean Different & $p$ \\
\hline \multirow{2}{*}{ Knowledge } & Pretest & 8,19 & 1,193 & \multirow{2}{*}{1,227} & \multirow{2}{*}{0,000} \\
\hline & post-test & 9,41 & 0,718 & & \\
\hline
\end{tabular}

Based on Table 3 known changes in average knowledge after training the application of ANC $10 \mathrm{~T}$ was 1,227 with a value of $p=0.000 . p=0.001<0.005$ can be concluded there was a difference in respondents' knowledge before and after training on the implementation of ANC $10 \mathrm{~T}$ in Dairi Regency, North Sumatra Province.

\subsubsection{Differences in Pretest and Post-test Midwife Knowledge Control Group in Dairi District}

Differences in the knowledge of pretest and post-test respondents were conducted 2 times as measured by paired t-tests at the control group.

Table 4. Distribution of Knowledge Value Changes before and after an ANC $10 \mathrm{~T}$ implementation training at Control group in Dairi Regency

\begin{tabular}{llllll}
\hline Variable & & Mean & SD & Mean Different & $\boldsymbol{p}$ \\
\hline \multirow{2}{*}{ Knowledge } & pre-test & 8,25 & 1,175 & \multirow{2}{*}{0,067} & 0,058 \\
& post-test & 8,32 & 1,105 & & \\
\hline
\end{tabular}

Based on table 4, it was known that the average difference in knowledge before (pre-test) and post-test in the control group are $0.067 \mathrm{p}$-value $=0.058<0.005$ then it can be concluded that there is no difference in knowledge value before and after pad control group that was not given training in the implementation of ANC $10 \mathrm{~T}$ in Dairi Regency, North Sumatra Province.

\subsection{Effectiveness of ANC 10 T Implementation Training}

The implementation of ANC $10 \mathrm{~T}$ in intervention groups and control groups in Dairi District using independent t-tests.

Table 5. Knowledge before and after training on the implementation of ANC $10 \mathrm{~T}$ in intervention and control group in Dairi regency

\begin{tabular}{llllll}
\hline Variable & & Group & Mean & SD & $\boldsymbol{p}$ \\
\hline \multirow{2}{*}{ Knowledge } & pretest & Intervention & 8,19 & 1,193 & 0,731 \\
\cline { 2 - 6 } & post-test & Control & 8,25 & 1,175 & $<, 708$ \\
& & Intervention & 9,41 & 1,105 & $<0,001$ \\
\cline { 2 - 6 } & \multirow{2}{*}{ average change } & Control & 8,32 & 0,831 & $<0,001$ \\
\hline
\end{tabular}

Based on Table 5, it was known that Before the ANC $10 \mathrm{~T}$ implementation training, respondents' knowledge of intervention and control groups was a value of $p=0.731$. This means no significance because there was no difference in knowledge in the intervention group and control group before (pretest) and After (post-test then knowledge p-value of $=0.000,<0.05$ then it can be concluded there was a difference in knowledge of intervention group and control group after (post-test) training of ANC $10 \mathrm{~T}$ application.

The difference in average knowledge of intervention group with control group before and after training of ANC 10 $\mathrm{T}$ p-value of $<0.001$, because p-value of $0.001<0.05$ concluded that training in the application of ANC $10 \mathrm{~T}$ effectively increased the knowledge of midwives in Dairi Regency 


\section{Discussion}

The productive lifespan, length of work, and education of respondents influenced the knowledge of midwives in the application of ANC $10 \mathrm{~T}$ to prevent maternal death. Based on the results of the research, it is known that there are still midwives who have less knowledge in the application of ANC $10 \mathrm{~T}$, namely a value below 8 as much as $25.3 \%$ in the intervention group and $21.3 \%$ of the control group.

The knowledge of midwives or respondents is low because there are still midwives who have never attended training on ANC $10 \mathrm{~T}$ from the Dairi District Health Office. This is following the statement of most respondents who stated that they have never received ANC $10 \mathrm{~T}$ training in Dairi because those invited to attend the ANC $10 \mathrm{~T}$ training are midwives coordinators at the Community Health Center (Puskesmas). Antenatal $10 \mathrm{~T}$ is service information according to the standards required for all midwives who perform antenatal examinations. In line with the research conducted by Ariyanti in Marniyati (2016) to eight Midwives Center for Public Health (Puskesmas) Purbalingga regency that states midwives need to gain knowledge about the latest antenatal service standards so that they can adapt to the science that is developing now.

Leslie's research (2012) showed there was a very positive and statistically significant relationship between knowledge of antenatal examination and antenatal service capabilities in midwives $(p<0.001)$. Efforts that can be made to improve knowledge include conducting technical training antenatal services according to standards, Puskesmas Coordinator Puskesmas and midwives routinely evaluate the performance of midwives in providing antenatal services.

Respondents' knowledge in the intervention group and control group before the ANC $10 \mathrm{~T}$ implementation training had almost the same average score and based on independent T-Test results it was known that there was no significant difference in knowledge, between the intervention group and the control group. This is in the opinion of Hennekens and Buring di Murti (2003) who stated that before conducting experimental research, it is recommended that group conditions should have comparable or balanced abilities with the aim of avoiding bias. Bias can occur in experimental studies. Research bias consists of selection bias and information bias so it is necessary to balance the ability of research subjects.

One of the strategies to gain knowledge according to WHO quoted by Notoatmodjo (2007) was to provide information to increase knowledge to increase awareness of increased knowledge and then impact on the change of midwives in the application of ANC $10 \mathrm{~T}$.

To increase knowledge, in the application of ANC $10 \mathrm{~T}$ in Dairi Regency, research was conducted training on the application of ANC $10 \mathrm{~T}$ to midwives who were used as intervention groups, and based on the results of research it was known that the average change in knowledge after training the application of ANC $10 \mathrm{~T}$ was 1,227. Knowledge has a value of $p=0.000 .<0.05$ can be concluded that there was a difference in the value of knowledge, to the application of ANC $10 \mathrm{~T}$ before and after the training of the implementation of ANC $10 \mathrm{~T}$ in Dairi Regency, North Sumatra Province.

Differences in knowledge changed, in intervention groups and control groups before and after training the application of ANC $10 \mathrm{~T}$ with a value of $p<0.001<0.05$ can be concluded that the training of the application of ANC $10 \mathrm{~T}$ effectively increases the knowledge of midwives to prevent maternal death in Dairi Regency of North Sumatra Province.

This increase in knowledge is due to new information obtained by midwives after training. One's knowledge was strongly influenced by the information obtained, this was by Suyono's statement in Tomastola (2015) that the provision of informative and interesting educational materials was a very strong driver in providing health counseling because it will quickly increase knowledge.

The results of this study are in line with Ruwayda (2016) conducted to 40 midwives in Jambi Regency Health Center found a link between knowledge $(p=0.014)$, training ( $p=0.031)$, supervision /supervision $(p=0.008)$, and workload $(p=0.012)$ with the application of antenatal midwife service standards by the Center for Public Health (Puskesmas).

Integrated ANC services related to physical examination (10T) can run well with the implementation of routine technical training to improve midwifery competency for midwives and other supporting training needed as well as laboratory examination training for lab analysts/lab officers including basic lab services Of Public Health Center (including STI examination training for HIV / AIDS) has not gone well.

\section{Conclusion}

Midwife knowledge increased after training in the implementation of ANC $10 \mathrm{~T}$ in Dairi district, North Sumatra. 
Prior knowledge training application of an ANC $10 \mathrm{~T}$ with $p=0.731$. This means that there is no difference in knowledge, control before (pretest) training application of ANC $10 \mathrm{~T}$. The average knowledge difference between pretest and post-test is 0.067 with a value of $p=0.058$ After the implementation of training the application of ANC $10 \mathrm{~T}$ was known knowledge variable value $\mathrm{p}<0.001$ Because the value $p<0.005$ it can be concluded that there was a difference in knowledge, in intervention groups and control groups after (post-test) training on the application of ANC $10 \mathrm{~T}$. Training on the application of ANC $10 \mathrm{~T}$ effectively improves the knowledge of midwives in Dairi Regency of North Sumatra Province. The suggestion that the training of the ANC $10 \mathrm{~T}$ application was very effective to increase the knowledge of midwives to prevent maternal death in the Dairi district.

\section{Competing Interests Statement}

The authors declare that there are no competing or potential conflicts of interest.

\section{References}

Aisyah, R. D., \& Susiatmi, S. A. (2017). Evaluasi Pelaksanaan Standar 10t Dalam Pelayanan Antenatal Terpadu. Jurnal Kebidanan, 9(01), 74-81.

Badan Penelitian Dan Pengembangan Kesehatan. (2010). Riset kesehatan dasar RIKESDAS) tahun 2010. Jakarta: Kementerian Kesehatan Republik Indonesia.

Kemenkes, R. I. (2017). Profil Kesehatan Indonesia Tahun 2017. Jakarta. Kementerian Kesehatan Republik Indonesia

Kementrian Kesehatan. (2015). Pedoman Pelayanan Ante Natal Care Terpadu Edisi Kedua. Kementrian Kesehatan Direktur Jendral Bina Kesehatan Masyarakat.

Kesehatan, Kementerian. (2018). Hasil Utama RISKESDAS 2018.

Murti, B. (2003). Prinsip dan Metodologi Riset Epidemiologi, Edisi Kedua, Jilid Pertama. Yogyakarta : Gajah Mada University Press.

Nortman, D. (1974). Parental age as a factor in pregnancy outcome and child development. Reports on population/family planning, No. 16. New York, NY: Population Council.

Notoatmodjo, S. (2007). Promosi Kesehatan \& Ilmu Perilaku. Jakarta: Rineka Cipta.

Nove, A., Matthews, Z., Neal, S., \& Camacho, A. V. (2014). Maternal mortality in adolescents compared with women of other ages: evidence from 144 countries. Lancet Glob Health, 2, e155-164.

Ruwayda, R. (2016). Pelaksanaan Standar Pelayanan Antenatal oleh Bidan di Puskesmas Kota Jambi. Media Kesehatan Masyarakat Indonesia, 12(2), 91-97.

Tomastola, Y. A., Mbonohu, S., \& Barangmanise, S. (2015). Tanggapan Pasien Diabetes Melitus Komplikasi Tentang Penggunaan Media Leaflet Dan Foto Bahan Makanan Pada Konseling Gizi Di Poli Gizi RSUP Prof. Dr. RD Kandou Manado. Jurnal GIZIDO, 7(1).

\section{Copyrights}

Copyright for this article is retained by the author(s), with first publication rights granted to the journal.

This is an open-access article distributed under the terms and conditions of the Creative Commons Attribution license (http://creativecommons.org/licenses/by/4.0/). 